\title{
Requirement for the RII $\beta$ Isoform of PKA, But Not Calcium- Stimulated Adenylyl Cyclase, in Visual Cortical Plasticity
}

\author{
Quentin S. Fischer, ${ }^{1}$ Christopher J. Beaver, ${ }^{1}$ Yupeng Yang, ${ }^{1}$ Yan Rao, ${ }^{1}$ Klara B. Jakobsdottir, ${ }^{1}$ Daniel R. Storm, ${ }^{2}$ \\ G. Stanley McKnight, ${ }^{2}$ and Nigel W. Daw ${ }^{1}$ \\ ${ }^{1}$ Department of Ophthalmology and Visual Science, Yale University School of Medicine, New Haven, Connecticut 06520, and ${ }^{2}$ Department of Pharmacology, \\ University of Washington School of Medicine, Seattle, Washington 98195
}

The cAMP-dependent protein kinase (PKA) signaling pathway plays a key role in visual cortical plasticity. Inhibitors that block activation of all PKA regulatory subunits ( $\mathrm{RI} \alpha, \mathrm{RI} \beta, \mathrm{RII} \alpha, \mathrm{RII} \beta)$ abolish long-term potentiation (LTP) and long-term depression (LTD) in vitro and ocular dominance plasticity (ODP) in vivo. The details of this signaling cascade, however, including the source of PKA signals and which PKA subunits are involved, are unknown. To investigate these issues we have examined LTP, LTD, and ODP in knock-out mice lacking either the two cortically expressed $\mathrm{Ca}^{2+}$-stimulated adenylyl cyclases (AC1 and AC8) or the predominant neocortical subunit of PKA $(\mathrm{RII} \beta)$. Here we show that plasticity remains intact in AC1/AC8 - / - mice, whereas ODP and LTD, but not LTP, are absent in RII $\beta-/-$ mice. We conclude that (1) plasticity in the visual cortex does not require the activity of known $\mathrm{Ca}^{2+}$-stimulated adenylyl cyclases, (2) the PKA dependence of ODP and LTD, but not LTP, is mediated by RII $\beta$-PKA, and (3) multiple isoforms of PKA contribute to LTD.

Key words: cAMP-dependent protein kinase; LTP; LTD; ocular dominance plasticity; monocular deprivation; visual cortex

\section{Introduction}

Ocular dominance plasticity (ODP), long-term potentiation (LTP), and long-term depression (LTD) share several requirements, including activation of NMDA receptors (NMDARs) and cAMP-dependent protein kinase (PKA). ODP produced by monocular deprivation (MD) during a critical period of development is blocked by inhibition of NMDARs or PKA (Bear et al., 1990; Daw et al., 1999; Beaver et al., 2001). Similarly, NMDA- and PKA-dependent LTP and LTD have been demonstrated, often using the same stimulation protocols, in both visual cortex and hippocampus (Frey et al., 1993; Kirkwood et al., 1993; Huang et al., 1994; Brandon et al., 1997; Nguyen and Kandel, 1997; Hensch et al., 1998a; Otmakhova et al., 2000; Liu et al., 2003). Finally, $\mathrm{Ca}^{2+}$ influx through NMDARs is essential for the induction of LTP or LTD in both regions (Tsumoto, 1992; Malenka, 1994).

Knock-out of the genes encoding $\mathrm{Ca}^{2+}$-stimulated adenylyl cyclases in mice (AC1/AC8-/- mice) blocks the activation of cAMP resultant from $\mathrm{Ca}^{2+}$ influx through NMDARs and blocks PKA- and transcription-dependent LTP in the hippocampus (Poser and Storm, 2001). Furthermore, membranes prepared from whole-brain extracts of these mice show no $\mathrm{Ca}^{2+}$. stimulated adenylyl cyclase activity (Wong et al., 1999). Based on these observations and the similarity in NMDA and PKA dependence for ODP, LTP, and LTD, we hypothesized that AC1/AC8

Received June 18, 2004; revised Sept. 5, 2004; accepted Sept. 6, 2004.

This research was supported by National Eye Institute Grants R01 EY00053 and EY11353 to N.W.D., National Institutes of Health Grant GM32875 to G.S.M., and the Connecticut Lions Eye Research Foundation. N.W.D. is a Senior Science Investigator of Research to Prevent Blindness. We thank Thomas Hughes and Adrienne LaRue for help and advice on genotyping, Patricia Donovan for animal care, and Satoshi Shimegi for comments on this manuscript.

Correspondence should be addressed to Quentin Fischer, Department of Ophthalmology and Visual Science, Yale University Medical School, 330 Cedar Street, New Haven, CT 06520-8061. E-mail: quentin.fischer@yale.edu. DOI:10.1523/JNEUROSCI.2409-04.2004

Copyright $\odot 2004$ Society for Neuroscience $\quad$ 0270-6474/04/249049-10\$15.00/0 serves a similar function in visual cortex, connecting $\mathrm{Ca}^{2+}$ influx through NMDARs to the activation of PKA, thereby playing a crucial role in the pathways for ODP, LTP, and LTD.

There is evidence, however, for some dissociation between the mechanisms underlying these different forms of plasticity in visual cortex. Hensch et al. (1998a) showed that knock-out of the RI $\beta$ subunit of PKA [despite compensation by RI $\alpha$ subunits (Amieux et al., 1997)] blocks LTP and LTD, but not ODP. In contrast, Rp-8-ClcAMPS (8-chloroadenosine-3', 5' -cyclic monophosphorothioate, Rp-isomer), which inhibits both RI- and RII-PKA, blocks not only LTP and LTD, but also abolishes ODP (Beaver et al., 2001; Liu et al., 2003). One reason for this difference may be that only RII subunits are localized to glutamate receptor complexes by A-kinase anchoring proteins (AKAPs) (Colledge and Scott, 1999), which enable PKA to regulate glutamate receptor-mediated synaptic activity (Rosenmund et al., 1994; Westphal et al., 1999; Tavalin et al., 2002). Moreover, RII $\beta$ is the predominant PKA subunit in neocortex (Cadd and McKnight, 1989; Ventra et al., 1996; Brandon et al., 1998). Thus, we hypothesized that ODP is independent of at least some forms of LTP and LTD and depends specifically on the activation of RII $\beta$-PKA.

In this study we have used $\mathrm{RII} \beta-/-$ and $\mathrm{AC} 1 / \mathrm{AC} 8-/-$ mice to further elucidate the cellular mechanisms underlying PKAdependent visual cortical plasticity. We provide evidence for the following conclusions. First, the PKA dependence of ODP, but not LTP, is mediated primarily, if not exclusively, by RII $\beta$-PKA. Second, multiple isoforms of PKA contribute to LTD. Finally, plasticity in visual cortex, unlike hippocampus, does not require the activity of known $\mathrm{Ca}^{2+}$-stimulated adenylyl cyclases.

\section{Materials and Methods}

All procedures used in this study were approved by the Animal Care and Use Committee at Yale University and conform to the guidelines of the National Institutes of Health and The Society for Neuroscience. 
Generation of knock-out and wild-type mice

The initial generation of RII $\beta-/-$ and $\mathrm{AC} 1 / \mathrm{AC} 8-/-$ mice has been described previously (Brandon et al., 1998; Wong et al., 1999). Here, to control for modifiers, mutants were subsequently back-crossed seven or more times into either 129 (129S1/SvImJ; Jackson Laboratories, Bar Harbor, ME) or B6 (C57BL/6; Taconic Farms Inc., Germantown, NY) lines for study. Knock-out and wild-type AC1/AC8 mice in a 129 background (AC129-/ - and AC129+/+ mice) or a B6 background (ACB6 $-/-$ and $\mathrm{ACB} 6+/+$ mice), and RII $\beta$ mice in a B6 background (RII $\beta-/-$ and $\operatorname{RII} \beta+/+)$, were obtained from long-established colonies at the University of Washington (Seattle, WA). Additional animals were obtained by heterozygous or homozygous crossings. For study we compared knockout mice (AC129-/-, ACB6-/-, or RII $\beta-/-$ ) with littermate and non-littermate wild-type mice (pooled as follows: WT129 mice $=$ $\mathrm{AC} 129+/+$ and 129 mice; or WTB6 mice $=\mathrm{ACB} 6+/+, \mathrm{RII} \beta+/+$, and B6 mice; because they were indistinguishable). Experiments were performed with the experimenters blind to genotype, and where possible experimental and control groups were interleaved. On completion of electrophysiology experiments, each mouse was genotyped by PCR analysis, using standard techniques.

\section{PCR analysis}

Tail samples were digested with a proteinase K solution, and the DNA was extracted using DNeasy kit from Qiagen (Valencia, CA). For RII $\beta$ genotyping the PCR primers $5^{\prime}$-AGG AGC TGG AGA TGC TGC CAA-3' and 5'-GTG GTT TGT CCA AAC TCA TCA ATG T-3' were used to identify the knock-out allele (194 bp), whereas the primers 5' -GCA GGA TGA GCA TCG AG-3' and 5' -TTC GAG AGT GAG GCG GA-3' were used to identify the wild-type allele $(330 \mathrm{bp})$. Amplifications were performed in $20 \mu \mathrm{l}$ volumes using buffer ( $10 \mathrm{~mm}$ Tris- $\mathrm{HCl}, \mathrm{pH}$ 9.2, $1.5 \mathrm{~mm}$ $\mathrm{MgCl}_{2}$, and $25 \mathrm{~mm} \mathrm{KCl}$ ), $1 \mu \mathrm{M}$ of each primer, $0.2 \mathrm{~mm} \mathrm{dNTPs,} 50 \%$ formamide, $5 \mathrm{~mm}$ DTT, $0.1 \mathrm{mg} / \mathrm{ml} \mathrm{BSA}, 0.1 \mathrm{U}$ of Taq polymerase (Invitrogen Carlsbad, CA), and $1 \mu \mathrm{l}$ of genomic DNA. For amplification of the RII $\beta$ knock-out allele, PCR was performed with an initial denaturation step at $96^{\circ} \mathrm{C}$ for $3 \mathrm{~min}$, followed by 40 cycles at $95^{\circ} \mathrm{C}$ for $1 \mathrm{~min}, 62^{\circ} \mathrm{C}$ for $1 \mathrm{~min}, 72^{\circ} \mathrm{C}$ for $30 \mathrm{sec}$, and one end cycle at $72^{\circ} \mathrm{C}$ for $2 \mathrm{~min}$. For amplification of the RII $\beta$ wild-type allele, PCR was performed with an initial denaturation step at $98^{\circ} \mathrm{C}$ for $1 \mathrm{~min}$, followed by 35 cycles at $94^{\circ} \mathrm{C}$ for $1 \mathrm{~min}, 55^{\circ} \mathrm{C}$ for $1 \mathrm{~min}, 72^{\circ} \mathrm{C}$ for $30 \mathrm{sec}$, and one end cycle at $72^{\circ} \mathrm{C}$ for $1.5 \mathrm{~min}$.

For AC1/AC8 genotyping the PCR primers $5^{\prime}$-GGT GGA TGT GGA ATG TGT GC- $3^{\prime}$ and $5^{\prime}$-GTT CAG ACA TCT GTG TCC AC- $3^{\prime}$ were used to identify the AC8 knock-out allele with bands at $280 \mathrm{bp}$, whereas the primers $5^{\prime}$-CGC AGA TCA CCA CCT CGA T-3' and 5'-CTG CCT CTC TAT TCT CTG G-3' were used for the identification of the AC8 wild-type allele (at $420 \mathrm{bp}$ ). Amplifications were performed in $50 \mu \mathrm{l}$ volumes using buffer as described above, $0.3 \mu \mathrm{m}$ each primer, $0.2 \mathrm{~mm}$ dNTPs, $0.1 \mathrm{U}$ of Taq polymerase and $5 \mu \mathrm{l}$ of genomic DNA. PCR was performed with an initial denaturation step at $96^{\circ} \mathrm{C}$ for $3 \mathrm{~min}$, followed by 25 cycles at $95^{\circ} \mathrm{C}$ for $1 \mathrm{~min}, 55^{\circ} \mathrm{C}$ for $1 \mathrm{~min}$, and $72^{\circ} \mathrm{C}$ for $4 \mathrm{~min}$ and one end cycle at $55^{\circ} \mathrm{C}$ for $1 \mathrm{~min}$ and $72^{\circ} \mathrm{C}$ for $10 \mathrm{~min}$. PCR products were resolved on a $2 \%$ agarose gel stained with ethidium bromide.

\section{In vivo experiments}

Monocular deprivation. Two different deprivation paradigms were studied: short-term (STMD) and long-term (LTMD). STMD entailed 4-9 d of deprivation beginning at postnatal day 24 (P24), whereas LTMD lasted 17-22 d and started at P21. In either case, suture of the left eye was performed under halothane anesthesia (1-2\%; Halocarbon Laboratories, River Edge, NJ) in a 2:1 mixture of nitrous oxide and oxygen. Lid margins for the left eye were trimmed, and the lids were sutured shut. An ear punch was made for identification, anesthesia was removed, and the mouse was allowed to recover before being returned to its home cage. Postoperative discomfort was alleviated by Carprofen $(0.15 \mathrm{mg} / \mathrm{ml}$; Pfizer, New York, NY) added to the water supply. Mice were checked daily to ensure that the lids remained closed and that there was no incidence of infection.

Electrophysiology. Electrophysiological procedures were adapted from those of Gordon and Stryker (1996). After deprivation, or at similar ages in nondeprived controls, mice were anesthetized by intraperitoneal injection of $50-60 \mathrm{mg} / \mathrm{kg}$ Nembutal (Abbott Laboratories, North Chicago, IL), supplemented by chlorprothixene $(10 \mathrm{mg} / \mathrm{kg}$, i.m.; Sigma, St. Louis, MO). Atropine ( $20 \mathrm{mg} / \mathrm{kg}$, s.c.; Optopics, Fairington, NJ) was injected to reduce secretions and the parasympathetic effects of the anesthetic agents, and dexamethasone (4 mg/kg, s.c.; American Reagent Laboratories, Shirley, NY) was administered to reduce cerebral edema. Core temperature was maintained at $37^{\circ} \mathrm{C}$ by a homeostatically controlled heating pad. Heart rate and respiration were monitored continuously. A tracheal tube (to maintain the airway) and an intraperitoneal catheter (for supplemental doses of Nembutal, $0.15-0.2 \mathrm{mg}$ ) were inserted. Lidocaine (0.02 mg, s.c.; Bimeda, Dublin, Ireland) was injected under the scalp, the animal was placed in a stereotaxic device, and a mixture of oxygen and room air was provided. A craniotomy was made over the right visual cortex, leaving the dura intact. Agar was applied to enhance recording stability and prevent desiccation. The eyelids were removed from both eyes, and the corneas protected thereafter by frequent application of silicon oil.

In each mouse, 18-30 cells were recorded in three to six vertical penetrations spaced evenly ( $\geq 200 \mu \mathrm{m}$ intervals) across the mediolateral extent of binocular primary visual cortex to avoid sampling bias. Care was taken to ensure that receptive field topography was appropriate for the binocular region of primary visual cortex. That is, as the electrode was moved from medial to lateral, receptive fields moved centrally and were located in the central $25^{\circ}$ of the superior contralateral hemifield (Drager, 1978; Wagor et al., 1980, Gordon and Stryker, 1996).

Receptive fields of isolated single units were plotted on a tangent screen using a hand-held projector. The preferred direction, orientation, size, and velocity of the stimulus were determined. Then, using the preferred stimulus, cells were rated for response quality (see below) and assigned to ocular dominance categories according to the seven-category scheme of Hubel and Wiesel (1962) based on the auditory discrimination of two independent listeners. Category 1 cells were driven exclusively by the contralateral eye, category 7 cells were driven exclusively by the ipsilateral eye, and category 4 cells were driven equally by both eyes (with intermediate scores reflecting the relative strength for binocular responses).

Data analysis. Response quality was assessed by rating the level of visually driven and spontaneous activity, each on a three-point scale $(1=$ low to $3=$ high). Ratings were averaged for each mouse to produce an activity index. Ocular dominance histograms were constructed, and weighted ocular dominance (WOD) scores were calculated for each mouse, using the following formula: WOD $=\left(1 / 6 G_{2}+2 / 6 G_{3}+3 / 6 G_{4}\right.$ $\left.+4 / 6 G_{5}+5 / 6 G_{6}+G_{7}\right) / N$, where $G_{\mathrm{i}}$ is the number of cells in ocular dominance category $\mathrm{i}$, and $N$ is the total number of cells. According to this scheme, a score of 1 would mean that all cells responded only to the ipsilateral eye, whereas a score of 0 would mean that all cells responded only to the contralateral eye. Ocular dominance histograms of normal mice had an average WOD of $\sim 0.28$, that is, dominated by the contralateral eye. For all measures, data for each knock-out or wild-type group was expressed as mean \pm SEM, and significance between groups was evaluated using $t$ tests.

\section{In vitro experiments}

Slice preparation. Mice aged P23-P31 were anesthetized with halothane and decapitated shortly after the disappearance of a tail reflex. The brain was removed and immediately placed in fresh, ice-cold oxygenated dissection buffer containing (in $\mathrm{mM}$ ): 215 sucrose, $2.5 \mathrm{KCl}, 1.25 \mathrm{NaH}_{2} \mathrm{PO}_{4}$, $26 \mathrm{NaHCO}_{3}, 10$ dextrose, $2.8 \mathrm{MgCl}_{2}$, and $1 \mathrm{CaCl}_{2}$. After $2 \mathrm{~min}$, coronal slices $(400 \mu \mathrm{m})$ were made from binocular primary visual cortex and collected in fresh, ice-cold oxygenated dissection buffer using a DSK 1000 microslicer. Slices were then transferred to a submersion holding chamber that contained fresh artificial CSF (ACSF) containing (in mM): 124 $\mathrm{NaCl}, 5 \mathrm{KCl}, 1.25 \mathrm{NaH}_{2} \mathrm{PO}_{4}, 26 \mathrm{NaHCO}_{3}, 10$ dextrose, $1.3 \mathrm{MgCl}_{2}$, and $2.5 \mathrm{CaCl}_{2}$, bubbled with $95 \% \mathrm{O}_{2} / 5 \% \mathrm{CO}_{2}$ at room temperature. Slices were allowed to recover in the holding chamber for a minimum of $90 \mathrm{~min}$ before recording. For recording, slices were transferred to a submersiontype chamber mounted on the stage of an upright microscope (BX50WI, Olympus) and held fixed by a grid of parallel nylon threads and perfused 
with ACSF at a rate of 3-4 $\mathrm{ml} / \mathrm{min}$. All experiments were performed at room temperature $\left(22-25^{\circ} \mathrm{C}\right)$.

Recording. Extracellular recordings were made from layers $2 / 3$ with glass electrodes $(<1 \mathrm{M} \Omega)$ filled with ACSF. Field potentials were evoked via electrical stimulation through a bipolar matrix stimulating electrode (MX21XEP, Frederick Haer) placed in the center of the cortical thickness (corresponding to layer 4). Changes in the amplitude of the maximal negative field potential (FP) were used to measure the magnitude of paired-pulse depression (PPD), LTP, and LTD.

Slices were stimulated at $0.05 \mathrm{~Hz}$ with a constant current pulse of 200 $\mu$ sec duration and 25-35 $\mu \mathrm{A}$ of current, which yielded a half-maximal response. Input-output curves were constructed on the basis of FP amplitudes obtained in response to stimulus intensities ranging from 20 to $50 \mu \mathrm{A}$. In some of the mice from each strain, the effects of paired-pulse stimulation were examined. In these animals the magnitude of PPD was measured by taking the ratio of the second to the first FP amplitude elicited by pairs of stimuli with an interstimulus interval of 30-200 msec. After at least $20 \mathrm{~min}$ of stable baseline recording, LTP was induced by theta-burst stimulation (TBS; consisting of 10 bursts at $5 \mathrm{~Hz}$, with each burst having five pulses at $100 \mathrm{~Hz}$, repeated five times at $0.1 \mathrm{~Hz}$ ), or LTD was induced by low-frequency stimulation (LFS; consisting of 900 pulses at $1 \mathrm{~Hz}$ ). We examined LTP induced by TBS, because inhibition in the cortical circuit has been shown to curtail plasticity induced by higherfrequency stimuli (Artola and Singer, 1987; Bear and Kirkwood, 1993).

Data analysis. Every six samples were averaged, and FP amplitudes were then normalized to baseline and expressed as the mean \pm SEM. The magnitude of LTP or LTD was calculated by comparing the average FP amplitude for the period 30-40 min after induction, with that for the period 10 min before induction. For input-output, PPD, LTP, and LTD, $t$ tests were used to compare averaged FP amplitudes measured in knockout and wild-type mice. In addition, two-factor ANOVAs (data not shown) revealed no significant difference for the effects of either genotype or the interaction between genotype and interstimulus interval, but only for interstimulus interval, on PPD. This result was the same for ACB6, AC129, or RII $\beta$ mice, whether knock-out or wild-type.

\section{Results}

\section{Cortical organization and responsiveness in mutants}

Isolated single-unit receptive fields were recorded in a series of three to six vertical penetrations spaced evenly across the mediolateral extent of binocular primary visual cortex to avoid sampling bias. Comparable with previous studies (Gordon and Stryker, 1996), binocular visual responses were obtained for penetrations within the lateral $600 \mu \mathrm{m}$ of primary visual cortex and collectively represented the central $25^{\circ}$ of the superior visual field, in both wild-type and knock-out mice. Regressions of receptive field-center azimuth versus mediolateral electrode position were used to assess retinotopic organization. In all mice this relationship appeared linear and was quantified as the slope of the regression line. By this measure, retinotopic organization was not significantly different between wild-type and knock-out mice, comparing WTB6 with ACB6 $-/-(42 \pm 3$ and $42 \pm 5 ; p=0.99$; $t$ test), WT129 with AC129-/ $-(33 \pm 7$ and $32 \pm 11 ; p=0.93 ; t$ test), and WTB6 with RII $\beta-1-$ mice $(42 \pm 3$ and $39 \pm 3 ; p=$ 0.37 ; $t$ test) (Fig. 1). Furthermore, this relationship was similarly precise in wild-type and knock-out mice, as demonstrated by the comparably high mean correlation coefficients for such regressions (Fig. 1, insets). An analysis of receptive field area also showed no significant difference between wild-type and knockout mice, comparing WTB6 with ACB6-/- and WTB6 with RII $\beta-/-$ mice ( $p=0.84$ and 0.52 , respectively; $t$ tests) (Fig. $2 A$ ). Finally, the frequency of unresponsive or poorly responsive cells in knock-out mice was less than, or equal to, that found in wildtype mice (Fig. 3A-G, category "uc"), and the vigor of visually driven responses (comparing WTB6 and ACB6-/-, $p=0.24$; WT129 and AC129-/-, $p=0.79$; WTB6 and RII $\beta-/-, p=$
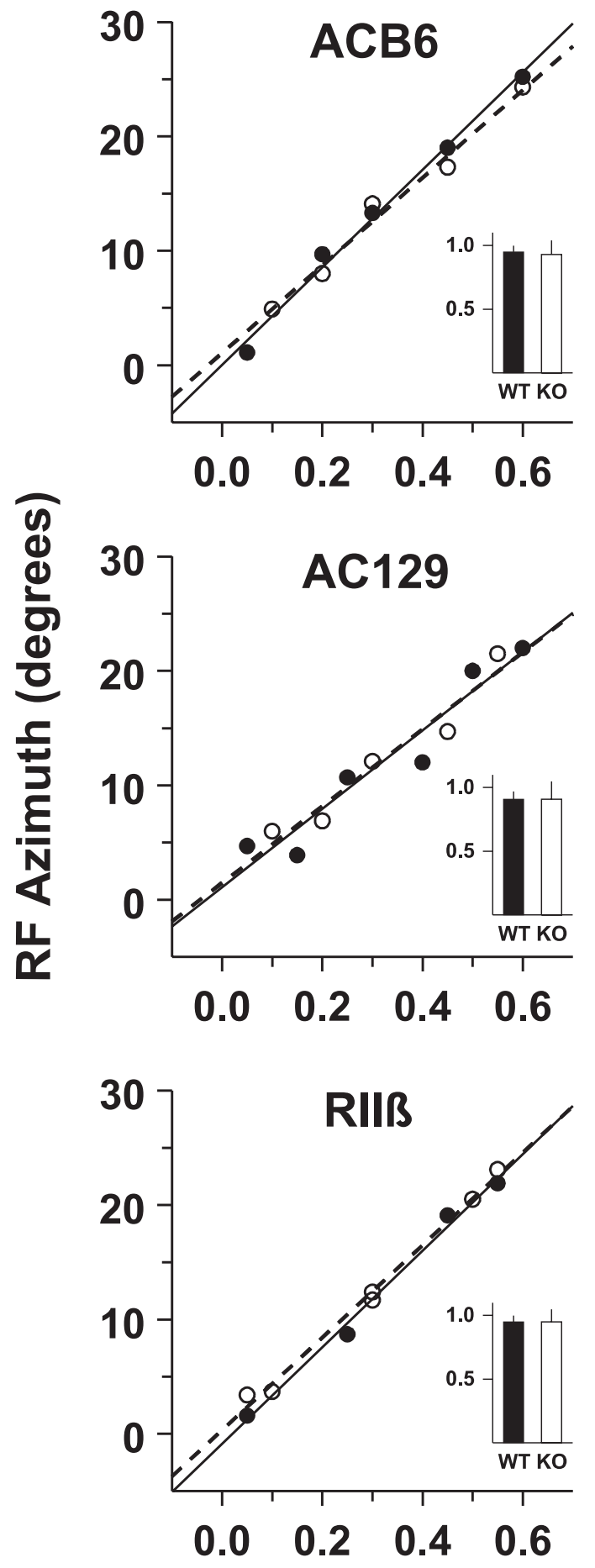

\section{L-M Electrode Position ( $\mathrm{mm}$ )}

Figure 1. Retinotopy is similar in wild-type and knock-out mice. Regressions of receptive field-center azimuth versus lateromedial electrode position, comparing the median cases for ACB6 - / - and WTB6 (top), AC129-/ - and WT129 (middle), and Rll $\beta-/-$ and WTB6 (bottom) mice. Insets are correlation coefficients for all mice of a particular wild-type (WT) or knock-out (K0) group (i.e., 6 ACB6 - / - and 11 WTB6; 5 AC129-/ - and 6 WT129; and 11 WTB6 and 11 RII $\beta-/-$ mice). Filled symbols/bars and solid lines represent wild-type mice, whereas open symbols/bars and dotted lines represent knock-out mice.

0.70 ; $t$ tests) (Fig. $2 B$ ) and level of spontaneous activity (comparing WTB6 and ACB6-/-, $p=0.29$; WT129 and AC129-/-, $p=0.92$; WTB6 and RII $\beta-1-, p=0.53$; $t$ tests) (Fig. $2 C$ ) were both similar in wild-type and knock-out mice. Therefore, any 
A
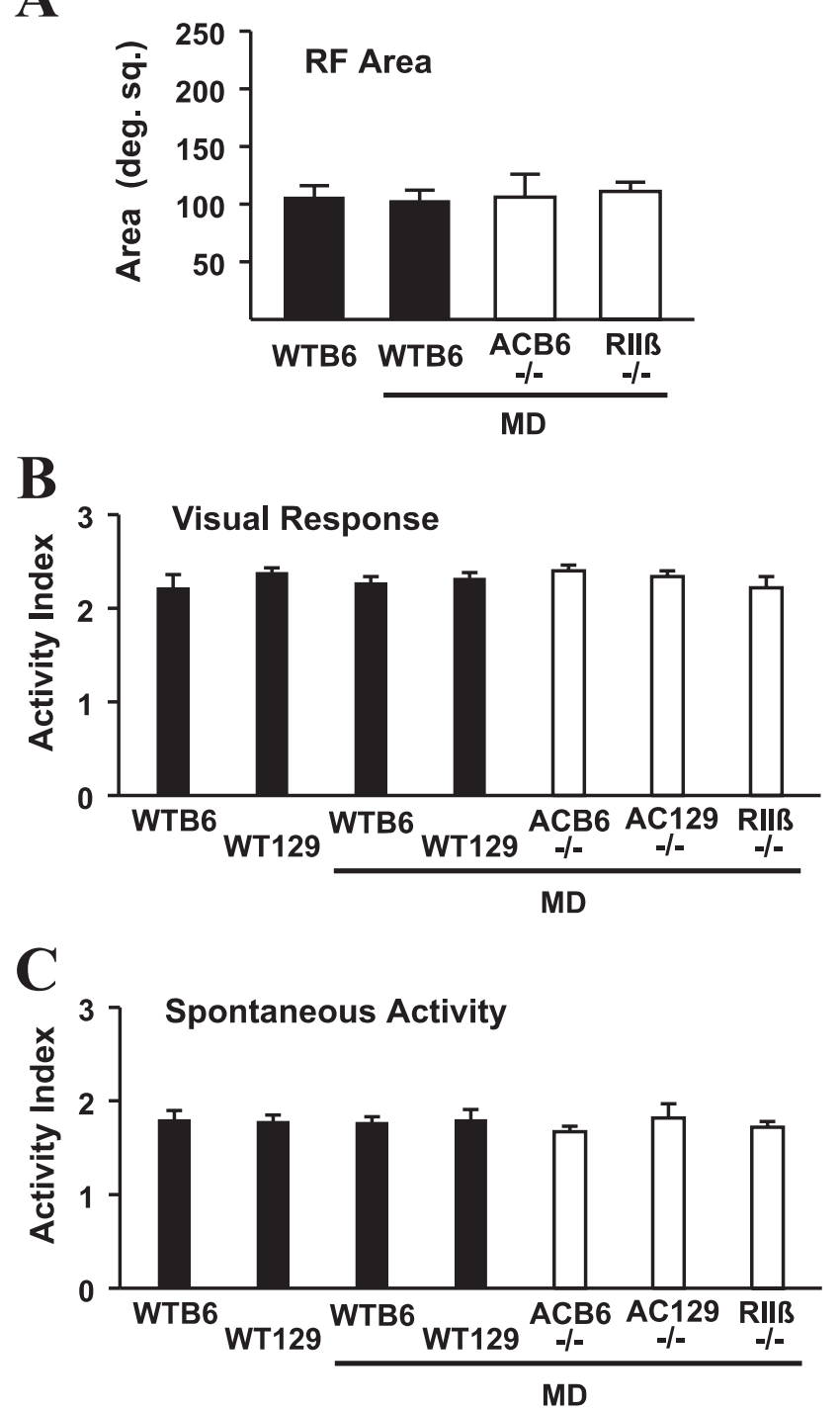

Figure 2. Receptive field area and response quality are similar in wild-type and knock-out mice. $A$, Receptive field area is similar in wild-type and knock-out mice. The histogram is based on 6 WTB6, 11 WTB6 MD, 5 ACB6 - / - MD, and 8 RII $\beta-/-M D$ mice (data were not collected for 129 background mice). $B, C$, The levels of visually driven and spontaneous activity were also similar in wild-type and knock-out mice, as rated on a three-point activity index ( $1=$ low to 3 = high; see Materials and Methods). Histograms are based on 6 WTB6, 6 WT129, 11 WTB6 MD, 6 WT129 MD, 6 ACB6 - / - MD, 5 AC129-/-MD, and 11 RII $\beta-/-$ MD mice. Other conventions as in Figure 1.

differences in cortical plasticity are not likely to be attributable to defects in the cortical organization or neuronal responsiveness of these mutants.

ODP is absent in RII $\beta-/-$ mice but normal in AC1/AC8-/- mice

Receptive fields of isolated single units were plotted on a tangent screen using a hand-held projector, the preferred direction, orientation, size and velocity of the stimulus were determined, and the optimal stimulus was then used to judge ocular dominance. Consistent with previous results (Drager, 1978; Gordon and Stryker, 1996), ocular dominance histograms in wild-type mice are normally biased in favor of the contralateral eye (Fig. $3 B, D$ ), and 4-9 d of MD beginning at P24 (STMD) produces a shift in ocular dominance toward the nondeprived eye (Fig. $3 A, C$ ). A
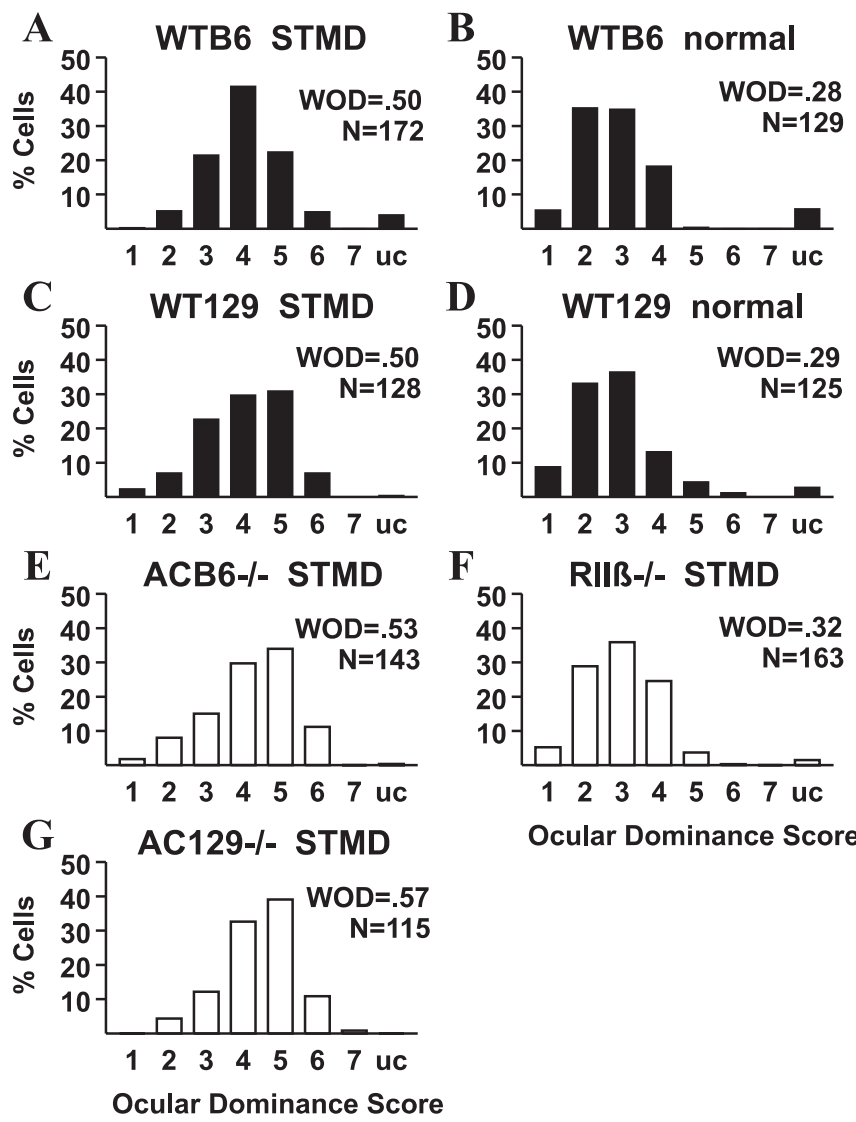

Ocular Dominance Score

Figure 3. Targeted deletion of the RII $\beta$ subunit of PKA, but not of $\mathrm{Ca}^{2+}$-stimulated adenylyl cyclases $\mathrm{AC} 1$ and $\mathrm{AC} 8$, blocks ocular dominance shifts. Ocular dominance histograms were constructed for wild-type (solid bars) and knock-out (open bars) mice. $A$, WTB6 mice with STMD $(n=7)$. B, Nondeprived WTB6 mice $(n=6)$. C, WT129 mice with STMD $(n=6)$. D, Nondeprived WT129 mice $(n=6)$. E, ACB6 $-/-$ mice with $\operatorname{STMD}(n=6)$. F, RII $\beta-/-$ mice with $\operatorname{STMD}(n=7$ mice). G, AC129-/ - mice with STMD $(n=5)$. Cells in ocular dominance category 1 are driven exclusively by the contralateral (closed) eye, whereas those in category 7 are driven exclusively by the ipsilateral (open) eye. Cells in category 4 are driven equally by both eyes. uc, Uncharacterized; $n$, number of cells.

similar ocular dominance shift, showing that plasticity is still intact, is seen after STMD in both strains of AC1/AC8 - / - mice (Fig. $3 E, G$ ); however, STMD in RII $\beta-/-$ mice produces an unshifted ocular dominance histogram, equivalent to that in nondeprived wild-type mice, indicating that plasticity has been abolished (Fig. 3, compare B, F).

Ocular dominance was further characterized by the calculation of WOD scores. WOD scores reflect the relative dominance of contralateral (deprived) versus ipsilateral (nondeprived) eye inputs pooled for each animal (see Materials and Methods). WOD scores in WTB6 and WT129 mice are closely similar, both with and without STMD (Fig. 4A). Normally their WOD scores are low $($ WTB6 $=0.28 \pm 0.02$ and WT129 $=0.29 \pm 0.02)$, indicating a prominent contralateral bias, but both show a significant increase in WOD scores with STMD $(0.50 \pm 0.02$ and $0.50 \pm 0.03$, respectively; $p<0.001$ for both cases; $t$ tests) (Fig. $4 A$ ). Similarly, ACB6-/- and AC129-/- mice with STMD have significantly higher WOD scores than nondeprived wildtype mice $(0.53 \pm 0.02$ vs $0.28 \pm 0.02$ and $0.57 \pm 0.04$ vs $0.29 \pm$ $0.02 ; p<0.001$ for both cases; $t$ tests) and show an ocular dominance shift comparable with STMD wild-type mice $(0.53 \pm 0.02$ vs $0.50 \pm 0.02$ and $0.57 \pm 0.04$ vs $0.50 \pm 0.03 ; p=0.18$ and 0.19 , respectively; $t$ tests) (Fig. $4 A$ ). In contrast, WOD scores for 

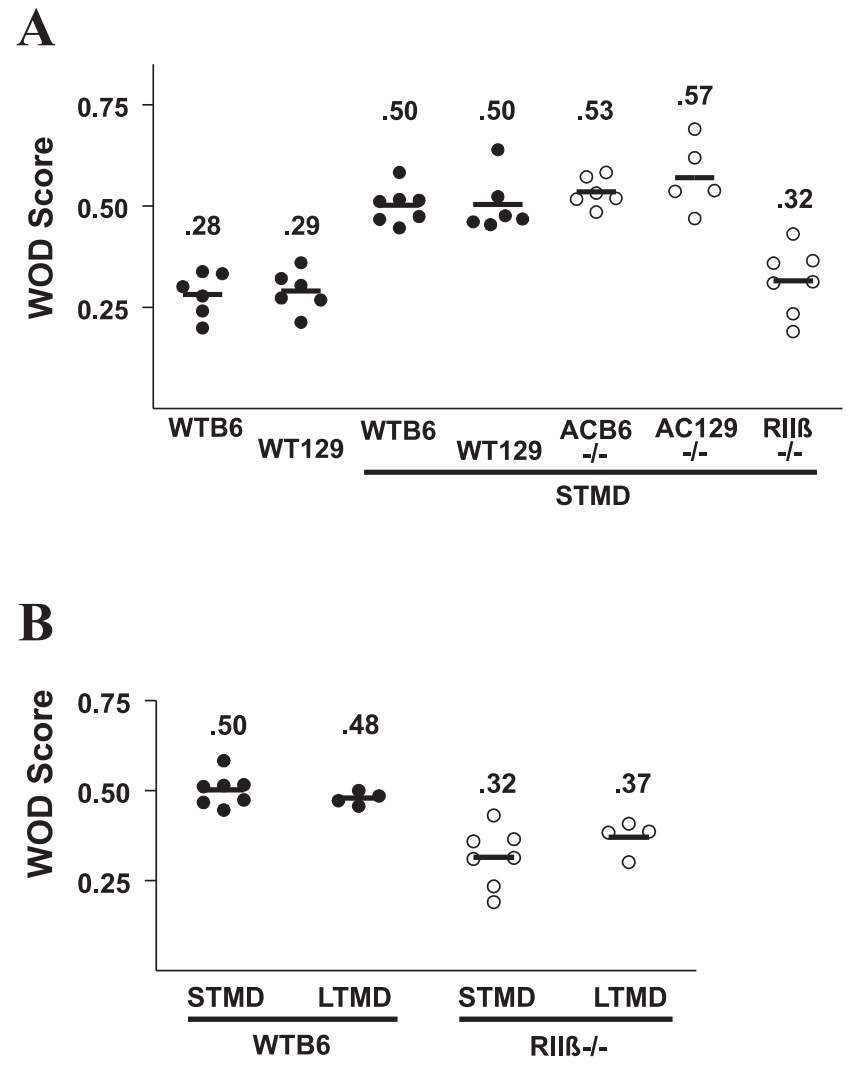

Figure 4. WOD scores are significantly increased by monocular deprivation in wild-type mice and $A C 1 / A C 8-/-$ mice, but not RII $\beta-/-$ mice. $A$, The effects of short-term deprivation restricted to the normal critical period. Each circle represents the WOD score for an individual mouse. Numbers above each group are the mean WOD score (also indicated as horizontal bars). See Materials and Methods for calculation of WOD scores. $B$, Comparison of short- and longterm deprivation effects on WOD scores in wild-type and RII $\beta-/-$ mice. Other conventions as in Figure 3.

RII $\beta-/-$ mice with STMD are not significantly different from normal wild-type mice $(0.32 \pm 0.03$ and $0.28 \pm 0.02 ; p=0.42 ; t$ test) (Fig. $4 A$ ) but are significantly different from STMD wildtype mice $(0.32 \pm 0.03$ and $0.50 \pm 0.02 ; p<0.001 ; t$ test $)$. These data strongly suggest that knock-out of the RII $\beta$ subunit of PKA, but not that of $\mathrm{Ca}^{2+}$-stimulated $\mathrm{ACl}$ and $\mathrm{AC} 8$, blocks ODP in mice.

Timing and sensitivity of the critical period in RII $\beta-/-$ mice Alternatively, the timing or sensitivity of the critical period to MD might be altered in RII $\beta-/-$ mice, as reported for some other transgenic strains (Hanover et al., 1999; Fagiolini and Hensch, 2000). To determine whether this was indeed the case, we examined ODP in RII $\beta-/-$ and WTB6 mice with an earlier-onset longer-lasting period of $\mathrm{MD}$ (17-22 $\mathrm{d}$ of MD beginning at $\mathrm{P} 21$, or LTMD). Because eye opening occurs at about P14 and the normal critical period extends for 1 week on either side of its P25 peak (Gordon and Stryker, 1996; Hanover et al., 1999), LTMD should reveal a shifted critical period any time within the first 50 postnatal days. Also, if deletion of the RII $\beta$ subunit reduces sensitivity to $\mathrm{MD}$, then LTMD should result in an increase in ODP relative to STMD; however, there is no significant difference in WOD scores between mice with STMD and those with LTMD, for either RII $\beta-/-$ mice $(0.32 \pm 0.03$ and $0.37 \pm 0.02$, respectively; $p=0.25 ; t$ test $)$ or WTB6 mice $(0.50 \pm 0.02$ and $0.48 \pm 0.01$, respectively; $p=0.36$; $t$ test) (Fig. $4 B$ ). Moreover, for either deprivation condition, RII $\beta-/-$ mice show significantly less ODP than WTB6 mice (STMD: $0.32 \pm 0.03$ vs $0.50 \pm 0.02, p<0.001, t$ test; LTMD: $0.37 \pm 0.02$ vs $0.48 \pm 0.01, p<0.005$, $t$ test, respectively) (Fig. $4 B$ ). Thus, it is unlikely that the deficit in ODP seen in RII $\beta-/-$ mice can be accounted for by a shift in the timing, or decrease in the sensitivity, of the critical period for ODP.

\section{LTP and LTD are normal in AC1/AC8-/- mice}

To test the hypothesis that the activation of adenylyl cyclase by $\mathrm{Ca}^{2+}$ influx through NMDARs underlies the induction of LTP and LTD in visual cortex, we investigated whether these forms of synaptic plasticity were intact in $\mathrm{AC} 1 / \mathrm{AC} 8-/-$ mice, because membranes from whole-brain extracts of these mutants are devoid of $\mathrm{Ca}^{2+}$-stimulated adenylyl cyclase activity (Wong et al., 1999). As an initial step we examined basal synaptic transmission. Slices obtained from wild-type (WTB6 or WT129) and AC1/ AC8-/- mice (ACB6-/- or AC129-/-) did not show any marked difference in the mean FP amplitude evoked by a range of input intensities ( $p>0.05$ for all cases; $t$ tests) (Figs. $5 A, 6 A$ ). Also, in AC1/AC8-/- mice, as in wild-type controls, pairedpulse stimulation resulted in a reduction of the FP amplitude evoked by the second stimulus (paired-pulse depression), the magnitude of which was indistinguishable between AC1/ AC8 $-/-$ mice and wild-type mice at all intervals tested (in either the $\mathrm{B} 6$ or 129 backgrounds, $p>0.05$ for all cases; $t$ tests) (Figs. $5 B$, $6 B$ ). This finding is consistent with previous results for pairedpulse stimulation in visual cortex (Castro-Alamancos and Connors, 1997; Rozas et al., 2001) and suggests that the probability of transmitter release and the development of inhibitory circuitry are normal in $\mathrm{AC} 1 / \mathrm{AC} 8-/-$ mice as well as in wild-type controls. Additionally, a comparison of wild-type and knock-out slices showed no obvious anatomical changes.

Having determined that the mechanisms underlying basal synaptic transmission were intact, we investigated long-term plasticity in AC1/AC8-/- mice. LTP induced by TBS (see Materials and Methods) was comparable in wild-type (WTB6 = $128.7 \pm 5.9 \%$; WT129 $=125.4 \pm 3.1 \%)$ and AC1/AC $8-/-$ mice $(\mathrm{ACB} 6-/-=129.4 \pm 3.4 \%$; AC129-/ $=123.5 \pm 4.2 \%$ ), with no significant difference in average FP amplitude 30-40 min after induction ( $p=0.93$ and 0.74 ; $t$ tests) (Figs. $5 C, 6 C$ ). Similarly, LTD induced by LFS (see Materials and Methods) in AC1/ $\mathrm{AC} 8-/-$ mice $(\mathrm{ACB} 6-/-=90.7 \pm 2.8 \%$ and $\mathrm{AC} 129-/-=$ $91.6 \pm 2.5 \%$, at $30-40 \mathrm{~min}$ after LFS) was indistinguishable from that seen in wild-type mice (WTB6 $=89.5 \pm 3.0 \%$ and WT129 $=$ $89.2 \pm 1.7 \%$, at $30-40 \mathrm{~min}$ after LFS; $p=0.77$ and 0.46 ; $t$ tests) (Figs. 5D, 6D).

\section{RII $\beta-/-$ mice lack LTD but have normal LTP}

LTP and LTD in vitro have been proposed to model experiencedependent plasticity in visual cortex (Kirkwood et al., 1995; Singer, 1995; Katz and Shatz, 1996; Rittenhouse et al., 1999; Heynen et al., 2003). Because PKA is crucial for LTP, LTD, and ODP (Beaver et al., 2001; Liu et al., 2003) but targeted deletion of the RI $\beta$ subunit blocks some forms of LTP and LTD without compromising ODP (Hensch et al., 1998a), we investigated whether these forms of LTP and LTD share a common requirement with ODP for the activation of the RII $\beta$ isoform of PKA (see above results).

Such a commonality between ODP and LTD is demonstrated by the complete blockade of LFS-induced LTD in RII $\beta-/-$ mice $(\mathrm{RII} \beta-/-=98.8 \pm 2.1 \%$ vs WTB6 $=89.5 \pm 3.0 \%$, at $30-40$ min after LFS; $p<0.02 ; t$ test) (Fig. 7D). In contrast, LTP induced by TBS in RII $\beta-/-$ mice is not significantly different from that in wild-type mice $(\operatorname{RII} \beta-/-=130.2 \pm 5.1 \%$ and $\mathrm{WTB} 6=$ 
$128.7 \pm 5.9 \%$, at $30-40$ min after TBS; $p=0.85$; $t$ test) (Fig. $7 C$ ), despite dramatic reductions in both the relative abundance of RII-PKA and total PKA activity in these mice (Amieux et al., 1997; Brandon et al., 1998). These results, however, do not merely reflect an inhibition of PKA activity as seen in Rp-8-Cl-cAMPS-treated animals, because the deficit in $\operatorname{RII} \beta-/-$ mice is specific to LTD and not LTP.

We also examined basal synaptic transmission in RII $\beta-/-$ mice, because mice lacking $\operatorname{RI} \beta$ subunits exhibit a deficit in presynaptic signaling (Brandon et al., 1997; Hensch et al., 1998a). In contrast, input-output relationships and pairedpulse depression are both comparable in RII $\beta-/-$ and wild-type mice (Fig. $7 A, B$ ) ( $p>0.05$ for all cases; $t$ tests), suggesting a postsynaptic role for RII $\beta$ subunits in LTD. This result is consistent with immunocytochemical studies showing that RII $\beta$ subunits are restricted primarily to distal dendrites, a prominent component of the postsynaptic density, and wholly absent from presynaptic terminals (Ludvig et al., 1990; Glantz et al., 1992; Colledge et al., 2000).

\section{Discussion}

This study has examined the cellular mechanisms underlying PKA-dependent plasticity in visual cortex. Our results demonstrate that knock-out of the RII $\beta$ subunit of PKA blocks both ODP and LTD but has no effect on basal synaptic transmission or LTP. They show further that mice lacking both known $\mathrm{Ca}^{2+}$ stimulated adenylyl cyclases (AC1 and AC8) display normal plasticity, including LTP, LTD, and ODP.

These findings have several important implications. First, they preclude known $\mathrm{Ca}^{2+}$-stimulated adenylyl cyclases as a requisite source of the cAMP-dependent signals underlying visual cortical plasticity. Second, they demonstrate that ODP is primarily, if not exclusively, mediated by a specific isoform of PKA (RII $\beta$-PKA). Finally, they show that multiple isoforms of PKA (RII $\beta$ and RI $\beta$ ) contribute to LTD in visual cortex.

\section{Technical considerations}

Knock-out of a gene may produce modifiers that can result, independent of the targeted gene, in plasticity impairment or mask impairment produced by lack of the deleted gene. Three factors make it improbable that such modifiers have influenced our results. First, all knock-out strains were backcrossed at least seven times into a 129 or B6 background. Second, results were indistinguishable in wild-type littermates (likely to have modifiers) and non-littermates (lacking modifiers). Third, plasticity was intact in two strains of $\mathrm{AC} 1 / \mathrm{AC} 8-/-$ mice, each bred into a different genetic background unlikely to produce the same modifiers.

The blockade of ODP and LTD observed in RII $\beta-/-$ mice raises another issue. Lack of a gene throughout development may affect circuit formation or cause compensatory changes by other
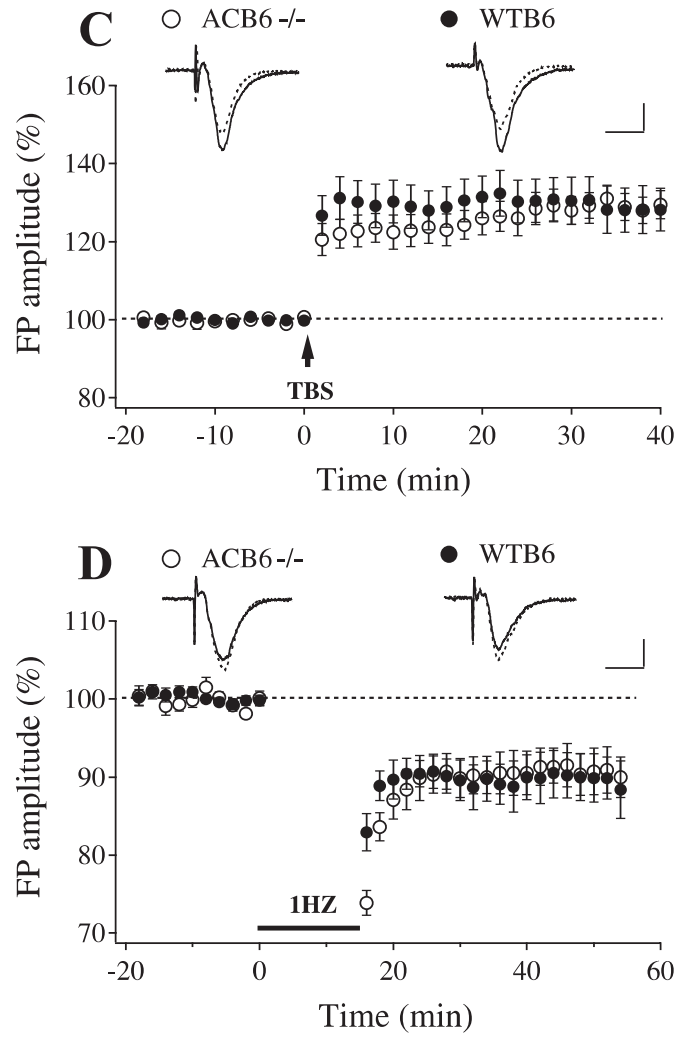

Figure 5. LTP and LTD are unaffected in AC1/AC8 knock-out mice in a B6 background. $A$, Input- output relationships are normal in ACB6 - / - mice, with no marked difference between WTB6 ( $n=8$ slices from 5 mice) and ACB6 $-/-(n=7$ slices from 5

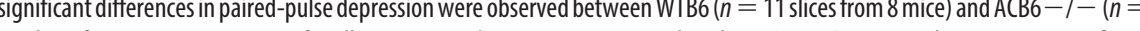
mice 30 - 40 min after TBS ( $p=0.93 ; t$ test). Waveform insets depict representative traces 2 min before (dashed line) and 40 min (solid line) TBS. Calibration: $0.2 \mathrm{mV}, 10 \mathrm{msec}$ D, LTD was induced in ACB6-/ - mice. The average FP amplitudes in WTB6 min after LFS ( $p=0.77 ; t$ test). Waveform insets depict representative traces $2 \mathrm{~min}$ before (dashed line) and $40 \mathrm{~min}$ after (solid line) LFS. Calibration: $0.2 \mathrm{mV}, 10 \mathrm{msec}$.

molecules that are instead the underlying cause of plasticity impairment. Ideally, we would have used a conditional knock-out that lacked RII $\beta$ subunits only in visual cortex and only during the critical period. Unfortunately, no such mutants are available; however, retinotopy, receptive field area, response quality, basal synaptic transmission, and LTP were all normal in RII $\beta-/-$ mice. Furthermore, acute application of PKA inhibitors directly to visual cortex also blocks ODP and LTD (Beaver et al., 2001; Liu et al., 2003). These data strongly suggest that neither wiring errors nor compensation is the cause of impaired plasticity in $\operatorname{RII} \beta-/-$ mice.

\section{Source of cAMP/PKA-dependent signals}

LTP, LTD, and ODP in visual cortex were unaffected by knockout of the genes encoding known $\mathrm{Ca}^{2+}$-stimulated adenylyl cyclases, $\mathrm{AC} 1$ and $\mathrm{AC} 8$. Consistent with our results, LTP is also normal in the dentate gyrus of $\mathrm{AC} 1-/-$ mice (Villacres et al., 1998); however, these results differ from reports showing a reduced magnitude and more rapid decay of LTP in the hippocampus of AC mutant mice (Wu et al., 1995; Villacres et al., 1998; Wong et al., 1999). This is not a consequence of the shorter time course used in our study, because the change in magnitude and decay rate are evident immediately after LTP induction in hip- 

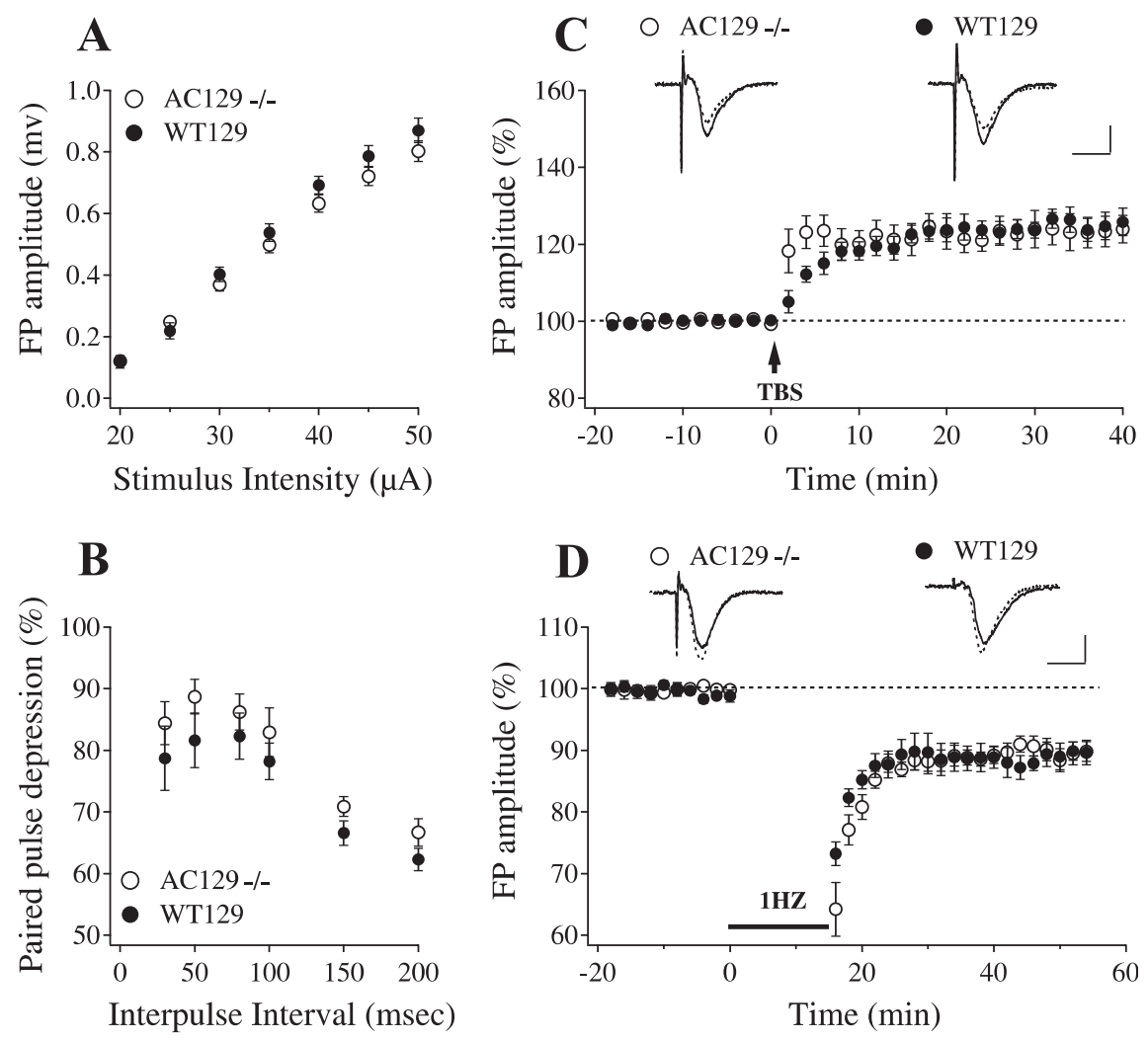

Figure 6. LTP and LTD are unaffected in AC1/AC8 knock-out mice in a 129 background. $A$, Input- output relationships are normal in AC129- / - mice, with no marked difference between WT129 ( $n=9$ slices from 5 mice) and AC129 - $/-(n=9$ slices from 7 mice) mice at each stimulus intensity ( $p>0.05$ for all cases; $t$ tests). $B$, Paired-pulse depression in WT129 and AC129-1mice. No significant differences in paired-pulse depression were observed between WT129 ( $n=9$ slices from 5 mice) and AC129- - - $n=12$ slices from 7 mice; $p>0.05$ for all cases; $t$ tests) mice. C, LTP was induced in AC129- - mice. There was no significant difference between the average FP amplitudes of WT129 $(n=6$ slices from 5 mice) and AC129- $/-(n=7$ slices from 6 mice) mice 30-40 min after TBS ( $p=0.74 ; t$ test). Waveform insets depict representative traces 2 min before (dashed line) and $40 \mathrm{~min}$ after (solid line) TBS. Calibration: $0.2 \mathrm{mV}, 10 \mathrm{msec}$. D, LTD was induced in AC129-/ - mice. The average FP amplitudes in WT129 mice ( $n=6$ slices from 5 mice) were not statistically different from those in AC129- $/-$ mice $(n=6$ slices from 6 mice) $30-40$ min after LFS ( $p=0.46 ; t$ test). Waveform insets depict representative traces 2 min before (dashed line) and $40 \mathrm{~min}$ after (solid line) LFS. Calibration: $0.2 \mathrm{mV}, 10 \mathrm{msec}$.

pocampus. Furthermore, it is unlikely that this reflects a difference in the stimulation protocols used to induce LTP, because virtually identical TBS protocols induce a cAMP-mediated transcription-dependent LTP in hippocampus and a long-lasting PKA-dependent LTP in visual cortex (Nguyen and Kandel, 1997; Liu et al., 2003). Hence, these data indicate that the generation of cAMP/PKA-dependent signals underlying plasticity in visual cortex and hippocampus is mechanistically distinct.

There are at least four possible alternative mechanisms for the activation of cAMP/PKA in visual cortex. First, another $\mathrm{Ca}^{2+}$ stimulated adenylyl cyclase may link $\mathrm{Ca}^{2+}$ influx through NMDARs to the activation of PKA. Second, NMDAR signaling may lead to the inhibition of phosphodiesterases that modulate basal levels of cAMP. Third, G-protein-coupled metabotropic glutamate receptors may stimulate AC via release of $\beta \gamma$ subunits, or activation of protein kinase C (Reid et al., 1996). Fourth, crosstalk with the extracellular signal-regulated kinase (ERK) pathway, which is also required for visual cortical plasticity (Di Cristo et al., 2001), may lead to PKA activation.

\section{RII-PKA and visual cortical plasticity}

All four PKA regulatory subunits, $\operatorname{RI} \alpha, \operatorname{RI} \beta, \operatorname{RII} \alpha$, and $\operatorname{RII} \beta$, are expressed in visual cortex (Cadd and McKnight, 1989; Ventra et al., 1996). Inhibition of all four subunits (Beaver et al., 2001) or knock-out of the $\mathrm{RII} \beta$ (present results), but not the RI $\beta$ subunit of PKA (Hensch et al., 1998a), blocks ODP. These data provide strong evidence that RII-, but not RI-, PKA is required for ODP, because RII $\beta-/-$ mice show a compensatory increase in RI subunits (Amieux et al., 1997; Brandon et al., 1998). Moreover, the apparent blockade of ODP in RII $\beta-/-$ mice probably reflects the relative scarcity of RII $\alpha$ subunits (Cadd and McKnight, 1989; Ventra et al., 1996), because our recent work indicates that both RII $\alpha$ and RII $\beta$ subunits play a role in ODP, although that of $\operatorname{RII} \beta$ is clearly predominant (Fischer et al., 2003; Rao et al., 2004; present results).

Only RII subunits are localized by AKAPs to the same plasticity substrates modified by LTD and MD. In hippocampus, AKAP150 targets RII-PKA to AMPA receptors (AMPARs), promoting phosphorylation of the Ser845 regulatory site of GluR1 subunits (Colledge et al., 2000; Tavalin et al., 2002). Changes in the phosphorylation state of this GluR1 PKA site regulate both AMPAR function (Banke et al., 2000) and synaptic trafficking (Ehlers, 2000), the two principal mechanisms proposed to account for LTD. NMDA-dependent LTD triggers the protein phosphatase-dependent dissociation of AKAP150/RII $\beta$-PKA complexes from AMPARs (Gomez et al., 2002; Smith and Dell'Acqua, 2003), dephosphorylation of GluR1 Ser845 (Lee et al., 2000), and removal of AMPARs from synaptic sites (Carroll et al., 1999; Ehlers, 2000).

In visual cortex, Heynen et al. (2003) have shown that MD or LTD produces a similar pattern of results, including dephosphorylation of GluR1 Ser845 and internalization of AMPARs. They also show that MD occludes LTD, supporting the hypothesis that altered AMPAR phosphorylation and/or surface expression contributes to ODP. Our own work in visual cortex demonstrates that ODP and LFS-induced LTD require both AKAP150 and RII $\beta$-PKA (Fischer et al., 2003; Rao et al., 2003; present results). Moreover, such LTD is both NMDA and protein phosphatase dependent (Kirkwood and Bear, 1994; Torii et al., 1995). Together these findings suggest that in visual cortex, like hippocampus, AKAP150 promotes the phosphorylation of GluR1 Ser 845 by RII $\beta$-PKA, and the NMDA- and protein phosphatase-dependent dissociation of AKAP150/RII $\beta$-PKA complexes, dephosphorylation of GluR1 Ser845, and internalization of AMPARs contribute to LTD and ODP. Thus, one possible interpretation of our results in $\mathrm{RII} \beta-/-$ mice is that a chronic dephosphorylation of GluR1 Ser845 produces a saturated LTD state that occludes the subsequent induction of LTD and ODP. This interpretation, however, must be reconciled with observations that PKA inhibitors have no effect on the baseline amplitude of field potentials, yet block induction of LFS-induced LTD in visual cortex (Liu et al., 2003).

These points can be reconciled by considering the effects of 
PKA on NMDARs. The AKAPs 150 and yotiao target protein phosphatases and RII-PKA to NMDARs (Westphal et al., 1999; Colledge et al., 2000). Within such complexes, protein phosphatases limit whereas PKA promotes NMDAR currents (Westphal et al., 1999). Inhibition of PKA would upset this balance, reducing or blocking the $\mathrm{Ca}^{2+}$-dependent activation of protein phosphatases required for the dissociation of AKAP150/RII $\beta$-PKA complexes from AMPARs, dephosphorylation of GluR1 Ser845, and internalization of AMPARs, but would not change basal synaptic transmission. This would explain why plasticity deficits in RII $\beta-/-$ mice are revealed only by MD-induced ODP and LFS-induced LTD, and why, apart from these deficits, visual physiology appears normal in RII $\beta-/-$ mice.

RII-PKA also modulates $\mathrm{GABA}_{\mathrm{A}}$ receptor function via an AKAP150dependent phosphorylation of receptor $\beta 1$ or $\beta 3$ subunits (McDonald et al., 1998; Brandon et al., 2003). This is potentially important because ODP is blocked by reducing, and can be restored by potentiating, GABA function (Hensch et al., 1998b). Fagiolini et al. (2004), however, have shown recently that these effects are mediated exclusively by $\mathrm{GABA}_{\mathrm{A}}$ receptor $\alpha 1$ subunits, which are colocalized with $\beta 2$, but not $\beta 1$ or $\beta 3$ subunits (Benke et al., 1994). Therefore, it is unlikely that the effects of RII-PKA are mediated by $\mathrm{GABA}_{\mathrm{A}}$ receptors.

PKA has also been implicated in a $\mathrm{Ca}^{2+} / \mathrm{cAMP}$-stimulated CRE-mediated gene transcription pathway essential for ODP. During the critical period, MD triggers $\mathrm{Ca}^{2+} / \mathrm{cAMP}$-dependent CRE-mediated gene expression in visual cortex (Pham et al., 1999). Furthermore, visually induced ERK activation requires PKA, whereas inhibition of ERK phosphorylation blocks CRE-mediated gene expression after visual stimulation (Cancedda et al., 2003). Moreover, ODP requires the activation of PKA, ERK, and cAMP response element-binding protein (CREB), as well as protein synthesis (Beaver et al., 2001; Di Cristo et al., 2001; Mower et al., 2002; Taha and Stryker, 2002). These findings have lead Berardi et al. (2003) to propose a $\mathrm{Ca}^{2+} /$ cAMP-PKA-ERK-CREB-CRE pathway for the regulation of ODP.

Mounting evidence indicates that RII isoforms fulfill the role of PKA in this pathway. Translocation and activation of RII-, but not RI-, PKA induces CREB phosphorylation that is necessary but insufficient for gene transcription (Constantinescu et al., 2002 ), whereas downregulation of RII $\beta$-PKA by antisense oligonucleotides inhibits cAMP-induced nuclear signaling and CREB phosphorylation (Paolillo et al., 1999). Furthermore, anchoring by AKAP150 increases the rate, magnitude, and sensitivity of PKA signaling to the nucleus, increasing by 10 -fold both CREB phosphorylation and CRE-mediated gene transcription (Feliciello et al., 1997). Finally, knock-out of RII-, but not RI-, PKA
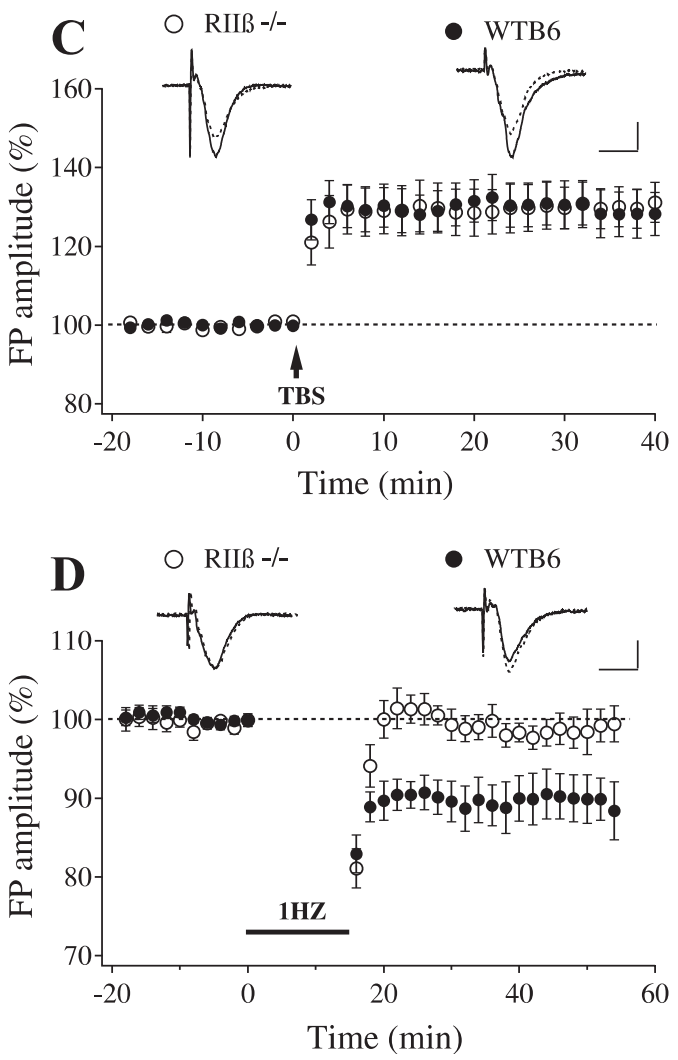

\section{0}

Figure 7. LTD is abolished, but LTP is normal, in RII $\beta$ knock-out mice. $A$, Input- output relationships are normal in RII $\beta-/-$ mice, with no marked difference between WTB6 ( $n=8$ slices from 5 mice) and RII $\beta-/-(n=12$ slices from 6 mice) mice at each stimulus intensity ( $p>0.05$ for all cases; $t$ tests). $B$, Paired-pulse depression in WTB6 and RII $\beta-/-$ mice. No significant between the average FP amplitudes of WTB6 ( $n=11$ slices from 10 mice) and RII $\beta-/-(n=10$ slices from 9 mice) mice $30-40$ min $0.85 ; t$ test). Waveform insets depict representative traces $2 \mathrm{~min}$ before (dashed line) and $40 \mathrm{~min}$ after (solid (B) TBS. Calibration: $0.2 \mathrm{mV}, 10 \mathrm{msec}$. D, LTD was abolished in RII $\beta-/-$ mice. The average FP amplitudes in wild-type mice 8 slices from 8 mice) were statistically different from those in Rll $\beta-1-$ mice $(n=8$ slices from 7 mice $) 30-40 \mathrm{~min}$ after LFS ( $p<0.02 ; t$ test). Waveform insets depict representative traces $2 \mathrm{~min}$ before (dashed line) and $40 \mathrm{~min}$ after (solid line) LFS. Calibration: $0.2 \mathrm{mV}, 10 \mathrm{msec}$.

subunits impairs ODP (Hensch et al., 1998a; Rao et al., 2004; present results).

\section{References}

Amieux PS, Cummings DE, Motamed K, Brandon EP, Wailes LA, Le K, Idzerda RL, McKnight GS (1997) Compensatory regulation of RI $\alpha$ protein levels in protein kinase A mutant mice. J Biol Chem 272:3993-3998.

Artola A, Singer W (1987) Long-term potentiation and NMDA receptors in rat visual cortex. Nature 330:649-652.

Banke TG, Bowie D, Lee H-K, Huganir RL, Schousboe A, Traynelis SF (2000) Control of GluR1 AMPA receptor function by cAMP-dependent protein kinase. J Neurosci 20:89-102.

Bear MF, Kirkwood A (1993) Neocortical long-term potentiation. Curr Opin Neurobiol 3:197-202.

Bear MF, Kleinschmidt A, Gu Q, Singer W (1990) Disruption of experience dependent synaptic modifications in striate cortex by infusion of an NMDA receptor antagonist. J Neurosci 10:909-925.

Beaver CJ, Ji Q-H, Fischer QS, Daw NW (2001) cAMP-dependent protein kinase mediates ocular dominance shifts in cat visual cortex. Nat Neurosci 4:159-163.

Benke D, Fritschy J-M, Trzeciak A, Bannwarth W, Mohler H (1994) Distribution, prevalence, and drug binding profile of $\gamma$-aminobutyric acid type A receptor subtypes differing in the $\beta$-subunit variant. J Biol Chem 269:27100-27107.

Berardi N, Pizzorusso T, Ratto GM, Maffei L (2003) Molecular basis of plasticity in the visual cortex. Trends Neurosci 26:369-378. 
Brandon EP, Idzerda RL, McKnight GS (1997) PKA isoforms, neural pathways and behaviour: making the connection. Curr Opin Neurobiol 7:397-403.

Brandon EP, Logue SF, Adams MR, Qi M, Sullivan SP, Matsumoto AM, Dorsa DM, Wehner JM, McKnight GS, Idzerda RL (1998) Defective motor behavior and neural gene expression in RII $\beta$-protein kinase A mutant mice. J Neurosci 18:3639-3649.

Brandon NJ, Jovanovic JN, Colledge M, Kittler JT, Brandon JM, Scott JD, Moss SJ (2003) A-kinase anchoring protein 79/150 facilitates the phosphorylation of $\mathrm{GABA}_{\mathrm{A}}$ receptors by cAMP-dependent protein kinase via selective interaction with receptor $\beta$ subunits. Mol Cell Neurosci 22:87-97.

Cadd GG, McKnight GS (1989) Distinct patterns of cAMP-dependent protein kinase gene expression in mouse brain. Neuron 3:71-79.

Cancedda L, Putignamo E, Impey S, Maffei L, Ratto GM, Pizzorusso T (2003) Patterned vision causes CRE-mediated gene expression in the visual cortex through PKA and ERK. J Neurosci 23:7012-7020.

Carroll RC, Lissin DV, von Zastrow M, Nicoll RA, Malenka RC (1999) Rapid redistribution of glutamate receptors contributes to long-term depression in hippocampal cultures. Nat Neurosci 2:454-460.

Castro-Alamancos MA, Connors BW (1997) Distinct forms of short-term plasticity at excitatory synapses of hippocampus and neocortex. Proc Natl Acad Sci USA 94:4161-4166.

Colledge M, Scott JD (1999) AKAPs: from structure to function. Trends Cell Biol 9:216-221.

Colledge M, Dean RA, Scott GK, Langeberg LK, Huganir RL, Scott JD (2000) Targeting of PKA to glutamate receptors through a MAGUK-AKAP complex. Neuron 27:107-119.

Constantinescu A, Gordon AS, Diamond I (2002) cAMP-dependent protein kinase types I and II differentially regulate cAMP response elementmediated gene expression. J Biol Chem 227:18810-18816.

Daw NW, Gordon B, Fox KD, Flavin HJ, Kirsch JD, Beaver CJ, Ji Q-H, Reid SM, Czepita D (1999) Injection of MK-801 affects ocular dominance shifts more than visual activity. J Neurophysiol 81:204-215.

Di Cristo G, Berardi N, Cancedda L, Pizzorusso T, Putignano E, Ratto GM, Maffei L (2001) Requirement of ERK activation for visual cortical plasticity. Science 292:2337-2340.

Drager UC (1978) Observations on monocular deprivation in mice. J Neurophysiol 41:28-42.

Ehlers MD (2000) Reinsertion or degradation of AMPA receptors determined by activity-dependent endocytic sorting. Neuron 28:511-525.

Fagiolini M, Hensch TK (2000) Inhibitory threshold for critical-period activation in primary visual cortex. Nature 404:183-186.

Fagiolini M, Fritschy J-M, Low K, Mohler H, Rudolph U, Hensch TK (2004) Specific $\mathrm{GABA}_{\mathrm{A}}$ circuits for visual cortical plasticity. Science 303:1681-1683.

Feliciello A, Li Y, Avvedimento EV, Gottesman ME, Rubin CS (1997) A-kinase anchor protein 75 increases the rate and magnitude of cAMP signaling to the nucleus. Curr Biol 7:1011-1014.

Fischer QS, Yang YP, Jakobsdottir KB, McKnight GS, Daw NW (2003) Type II PKA and its localization by AKAP150 is crucial for ocular dominance plasticity in mice. Soc Neurosci Abstr 29:37.9.

Frey U, Huang Y-Y, Kandel ER (1993) Effects of cAMP simulate a late stage of LTP in hippocampal CA1 neurons. Science 260:1661-1664.

Glantz SB, Amat JA, Rubin CS (1992) cAMP signaling in neurons: patterns of neuronal expression and intracellular localization for a novel protein, AKAP150, that anchors the regulatory subunit of cAMP-dependent protein kinase II $\beta$. Mol Biol Cell 3:1215-1228.

Gomez LL, Alam S, Smith KE, Horne E, Dell'Acqua ML (2002) Regulation of A-kinase anchoring protein 79/150-cAMP-dependent protein kinase postsynaptic targeting by NMDA receptor activation of calcineurin and remodeling of dendritic actin. J Neurosci 22:7027-7044.

Gordon JA, Stryker MP (1996) Experience-dependent plasticity of binocular responses in the primary visual cortex of the mouse. J Neurosci $16: 3274-3286$.

Hanover JL, Huang ZJ, Tonegawa S, Stryker MP (1999) Brain-derived neurotrophic factor overexpression induces precocious critical period in mouse visual cortex. J Neurosci 19:RC40(1-5).

Hensch TK, Gordon JA, Brandon EP, McKnight GS, Iderzda RL, Stryker MP (1998a) Comparison of plasticity in vivo and in vitro in the developing visual cortex of normal and protein kinase A RI $\beta$-deficient mice. J Neurosci 18:2108-2117.
Hensch TK, Fagiolini M, Mataga N, Stryker MP, Baekkeskov S, Kash SF (1998b) Local GABA circuit control of experience-dependent plasticity in developing visual cortex. Science 282:1504-1508.

Heynen AJ, Yoon B-J, Liu C-H, Chung HJ, Huganir RL, Bear MF (2003) Molecular mechanism for loss of visual cortical responsiveness following brief monocular deprivation. Nat Neurosci 6:854-862.

Huang Y-Y, Li XC, Kandel ER (1994) cAMP contributes to mossy fiber LTP by initiating both a covalently mediated early phase and macromolecular synthesis-dependent late phase. Cell 79:69-79.

Hubel DH, Wiesel TN (1962) Receptive fields, binocular interaction and functional architecture in the cat's visual cortex. J Physiol (Lond) 160:106-154.

Katz LC, Shatz CJ (1996) Synaptic activity and the construction of cortical circuits. Science 274:1133-1138.

Kirkwood A, Bear MF (1994) Homosynaptic long-term depression in the visual cortex. J Neurosci 14:3404-3412.

Kirkwood A, Dudek SM, Gold JT, Aizenman CD, Bear MF (1993) Common forms of synaptic plasticity in the hippocampus and neocortex in vivo. Science 260:1518-1521.

Kirkwood A, Lee HK, Bear MF (1995) Co-regulation of long-term potentiation and experience-dependent synaptic plasticity in visual cortex by age and experience. Nature 375:328-331.

Lee H-K, Barbarosie M, Kameyama K, Bear MF, Huganir RL (2000) Regulation of distinct AMPA receptor phosphorylation sites during bidirectional synaptic plasticity. Nature 405:955-959.

Liu S, Rao Y, Daw NW (2003) Roles of protein kinase A and protein kinase $\mathrm{G}$ in synaptic plasticity in the visual cortex. Cereb Cortex 13:864-869.

Ludvig N, Ribak CE, Scott JD, Rubin CS (1990) Immunocytochemical localization of the neural-specific regulatory subunit of the type II cyclic AMP-dependent protein kinase to postsynaptic structures in the rat brain. Brain Res 520:90-102.

Malenka RC (1994) Synaptic plasticity in the hippocampus: LTP and LTD. Cell 78:535-538.

McDonald BJ, Amato A, Connolly CN, Benke D, Moss SJ, Smart TG (1998) Adjacent phosphorylation sites on $\mathrm{GABA}_{\mathrm{A}}$ receptor $\beta$ subunits determine regulation by cAMP-dependent protein kinase. Nat Neurosci 1:23-28.

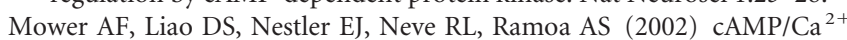
response element-binding protein function is essential for ocular dominance plasticity. J Neurosci 22:2237-2245.

Nguyen PV, Kandel ER (1997) Brief $\theta$-burst stimulation induces a transcription-dependent late phase of LTP requiring CAMP in area CA1 of the mouse hippocampus. Learn Mem 4:230-243.

Otmakhova NA, Otmakhov N, Mortenson LH, Lisman JE (2000) Inhibition of the cAMP pathway decreases early long-term potentiation at CA1 hippocampal synapses. J Neurosci 20:4446-4451.

Paolillo M, Feliciello A, Porcellini A, Garbi C, Bifulco M, Schinelli S, Ventra C, Stabile E, Ricciardelli G, Schettini G, Avvedimento EV (1999) The type and the localization of cAMP-dependent protein kinase regulate transmission of cAMP signals to the nucleus in cortical and cerebellar granule cells. J Biol Chem 274:6546-6552.

Pham TA, Impey S, Storm DR, Stryker MP (1999) CRE-mediated gene transcription in neocortical neuronal plasticity during the developmental critical period. Neuron 22:63-72.

Poser S, Storm DR (2001) Role of $\mathrm{Ca}^{2+}$-stimulated adenylyl cyclases in LTP and memory formation. Int J Dev Neurosci 19:387-394.

Rao Y, McKnight GS, Daw NW (2003) Synaptic plasticity in PKA RII $\alpha$ and AKAP150 knock-out mouse visual cortex. Soc Neurosci Abstr 29:584.11.

Rao Y, Fischer QS, Yang Y, McKnight GS, Daw NW (2004) Reduced ocular dominance plasticity and long-term potentiation in developing visual cortex of RII $\alpha$ mutant mice. Eur J Neurosci 20:837-842.

Reid SNM, Daw NW, Gregory DS, Flavin H (1996) cAMP levels increased by activation of metabotropic glutamate receptors correlate with visual plasticity. J Neurosci 16:7619-7626.

Rittenhouse CD, Shouval HZ, Paradiso MA, Bear MF (1999) Monocular deprivation induces homosynaptic depression in visual cortex. Nature 397:347-350.

Rosenmund C, Carr DW, Bergeson SE, Nllaver G, Scott JD, Westbrook GL (1994) Anchoring of protein kinase A is required for modulation of AMPA/kainate receptors on hippocampal neurons. Nature 368:853-856.

Rozas C, Frank H, Heynen AJ, Morales B, Bear MF, Kirkwood A (2001) Developmental inhibitory gate controls the relay of activity to the superficial layers of the visual cortex. J Neurosci 21:6791-6801. 
Singer W (1995) Development and plasticity of cortical processing architectures. Science 270:758-764.

Smith KE, Dell'Acqua ML (2003) NMDA receptor-calcineurin pathways implicated in LTD induce changes in the localization of AKAP79/150 and PKA RII $\beta$. Soc Neurosci Abstr 29:584.10.

Taha S, Stryker MP (2002) Rapid ocular dominance plasticity requires cortical but not geniculate protein synthesis. Neuron 34:425-436.

Tavalin SJ, Colledge M, Hell JW, Langeberg LK, Huganir RL, Scott JD (2002) Regulation of GluR1 by the A-kinase anchoring protein 79 (AKAP79) signaling complex shares properties with long-term depression. J Neurosci 22:3044-3051.

Torii N, Kamishita T, Otsu Y, Tsumoto T (1995) An inhibitor for calcineurin, FK506, blocks induction of long-term depression in rat visual cortex. Neurosci Lett 185:1-4.

Tsumoto T (1992) Long-term potentiation and long-term depression in the neocortex. Prog Neurobiol 39:209-228.

Ventra C, Porcellini A, Feliciello A, Gallo A, Paolillo M, Mele E, Avvedimento VE, Schettini G (1996) The differential response of protein kinase A to cyclic AMP in discrete brain areas correlates with the abundance of regulatory subunit II. J Neurochem 66:1752-1761.

Villacres EC, Wong ST, Chavkin C, Storm DR (1998) Type I adenylyl cyclase mutant mice have impaired mossy fiber long-term potentiation. J Neurosci 18:3186-3194.

Wagor E, Mangini NJ, Pearlman AL (1980) Retinotopic organization of striate and extrastriate visual cortex in the mouse. J Comp Neurol 193:187-202.

Westphal RS, Tavalin SJ, Lin JW, Alto NM, Fraser DC, Langeberg LK, Sheng M, Scott JD (1999) Regulation of NMDA receptors by an associated phosphatase-kinase signaling complex. Science 285:93-96.

Wong ST, Athos J, Figueroa XA, Pineda V, Schaefer ML, Chavkin C, Muglia LJ, Storm DR (1999) Calcium-stimulated adenylyl cyclase activity is critical for hippocampus-dependent long-term memory and late phase LTP. Neuron 23:787-798.

Wu Z-L, Thomas SA, Villacres EC, Xia Z, Simmons ML, Chavkin C, Palmitter RD, Storm DR (1995) Altered behavior and long-term potentiation in type I adenylyl cyclase mutant mice. Proc Natl Acad Sci USA 92:220-224. 